\title{
En Steno-epoke i dansk kunst \\ - og ukendte vaerker med geologen Steno som motiv
}
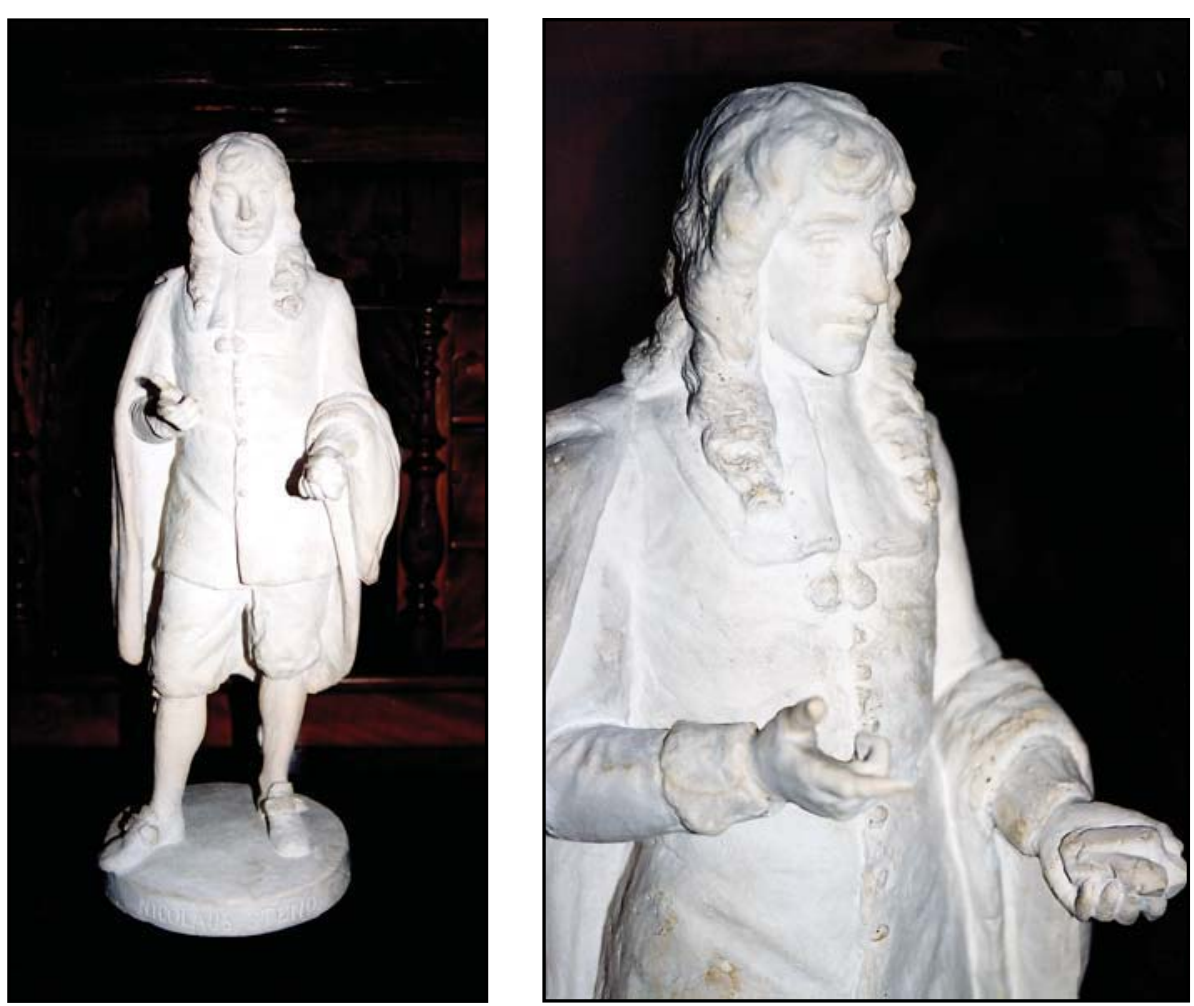

Laurits Jensens statuette af Niels Stensen set fra forskellige vinkler. (Fo

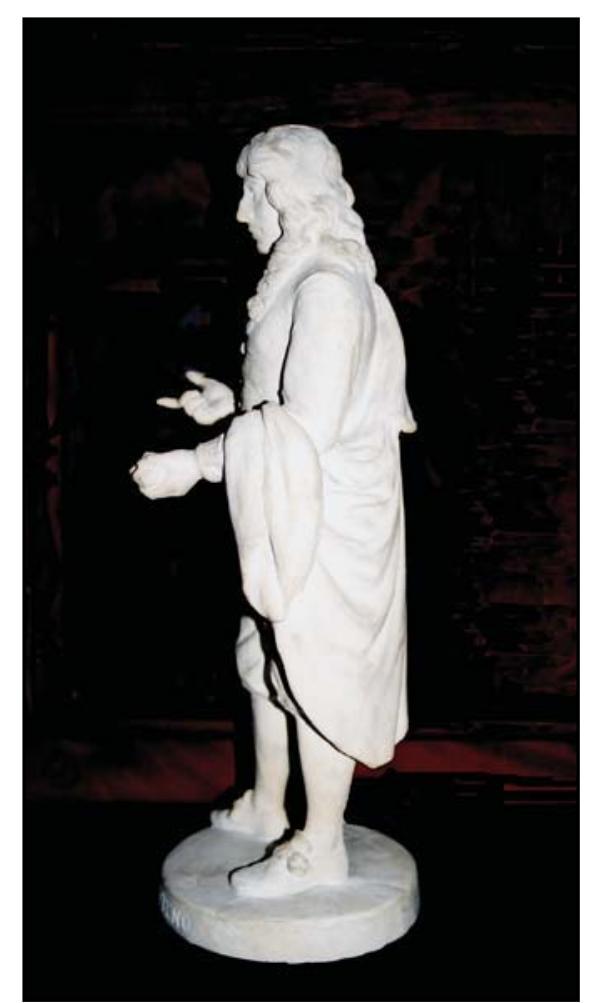

Forfatteren)
Af førsteamanuensis Elsebeth Thomsen, Geologisk Fagenhet, Tromsø Museum Universitetsmuseet

Det er ikke hver dag, man falder over et ukendt kunstværk, en statuette, som forestiller Niels Stensen som geolog. Faktisk kender jeg i skrivende stund ikke noget andet billedhuggerarbejde, som kun fremstiller geologen, og derfor syntes jeg, at denne "opdagelse" fortjente omtale.

Arbejdet med en artikel førte imidlertid til flere overraskelser, blandt andet tre ukendte malerier med Niels Stensen som motiv, heraf mindst to, hvor han optræder som geolog. Det ene af disse vises i denne artikel, som også afslører en Steno-epoke i dansk kunst.

\section{Laurits Jensens statuette}

23. november 2004 opdagede jeg ved et tilfælde en statuette som forestillede Niels Stensen som geolog. Den meget smukke gipsfigur befandt sig oppe på et højt skab på et kontor på Geologisk Museum i København. Det er sandsynligvis den høje place- ring, som gør, at den har stået upåagtet, da man bare ser den øverste del af figuren nedefra. For den som interesserer sig for Niels Stensen og kender det berømte portræt fra Uffizerne og Oscar Matthiesens freskoarbejde på Geologisk Museum, vil fysiognomien til personen nok medføre et stort ønske om et nærmere eftersyn. Dette blev umiddelbart imødekommet takket være velvilje fra Bestyrer, Professor Minik Rosing.

Statuetten forstiller ganske rigtigt Niels Stensen. Der står tydeligt "Nicolaus Steno" på soklen. Statuetten er ca. $37 \mathrm{~cm}$ høj og forestiller Niels Stensen, som demonstrerer krystaller. Det er altså geologen, som blandt andet opdagede kantvinklens konstans (Stenos Lov), der er emnet for kunstneren. Figuren er fint proportioneret og viser Niels Stensen i barokdragt, ikke i præste- eller bispedragt.

Statuetten er støbt i gips og signeret “Laurits Jensen 1915". Gips er ikke et godt materiale med henblik på bevaring for eftertiden, og statuetten viser da også spor efter brud. Hårdest er det gået ud over de spinkle arme, ben og fingre, men nogen har samvittighedsfuldt limet den sammen igen, og den holder nu sammen med de begrænsninger, som gammel udtørret lim giver. Selve støb- ningen giver et noget ufærdigt præg, som formodentlig indikerer, at dette ikke var ment som et endeligt produkt, men snarere et modeludkast, måske til en større statue, som aldrig blev til noget.

Eftersom arbejdet er signeret, ved vi imidlertid hvem kunstneren var, og hvornår statuetten blev færdig. Laurits Jensen blev født 1859 i Viborg og døde 1935 i København. Han var elev af V. Bissen og var i sin tid en anerkendt billedhugger, som mest er kendt for sine fremstillinger af dyr. Hans statuetter opnåede en stor popularitet i samtiden på grund af nøjagtigheden i gengivelsen og hans evne til at indfange modellens væsen. Man kan roligt sige, at han også klarede at indfange Niels Stensens væsen på en meget smuk måde i den omtalte statuette.

Laurits Jensen har også fremstillet udkast til store arbejder af mennesker, helst rytterfigurer, fx rytterfiguren af Kong Christian IX, der findes som en bronzestatuette på det Nationalhistoriske Museum på Frederiksborg Slot. Hans største arbejde var en rytterstatue af General Sherman til Chicago. Denne statue var oprindelig planlagt af en anden dansk kunstner, som døde. Det tog Laurits Jensen 5 år at fuldføre dette store værk, som han kun havde et meget lille økonomisk 

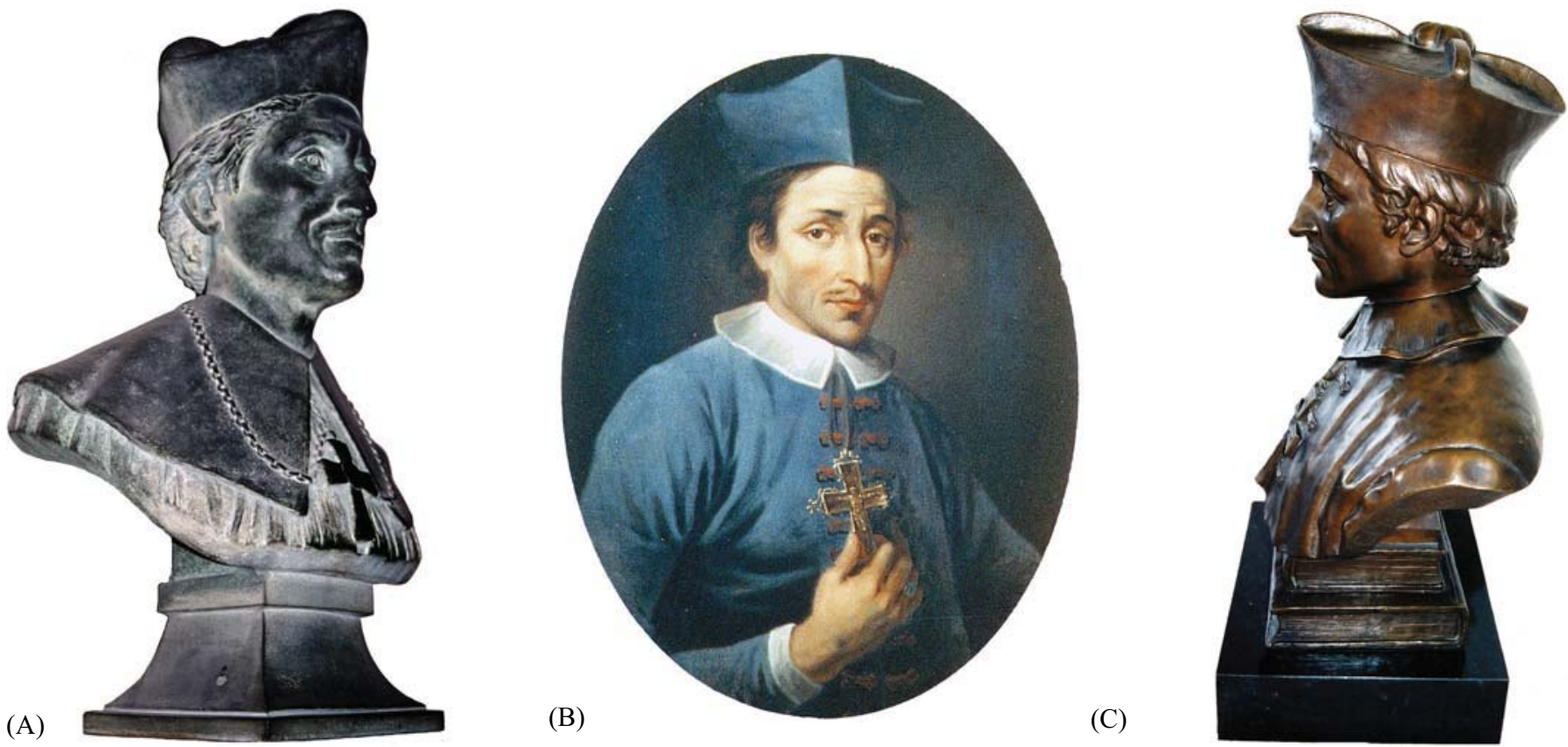

(A) Carl Hartmanns buste i Jesu Hjerte Kirke (Foto: Forfatteren). (B) C.A. Lorentzens maleri på Panum Instituttet (Foto: Panum Instituttet). (C). Elias Ølsgaards buste fra STENO-apoteket (Foto: Forfatteren)

overskud på. Som kunstner var han også engageret af den velrenommerede " $P$. Ibsens Enkes Terracottafabrik" i København, og deltog på Verdensudstillingen i Paris i år 1900 med flere arbejder, som han havde udført i regi af fabrikken. Et værk "To jagthunde, der står for hønsene", fik sølvmedalje. Flere af hans mindre arbejder blev modelleret til bronze eller produceret $i$ terracotta og i porcelæn (for Bing \& Grøndahl og den Kongelige Porcelainsfabrik). Jensens statuette af Niels Stensen har det ikke været muligt at opspore i litteratur/kataloger/arkiv. Noget, som også taler for, at den var et udkast til et arbejde, som ikke blev til noget.

Laurits Jensen skildres som flittig, trofast, beskeden, nøjsom, stilfærdig, mild og god. Et menneske som levede med og for sit arbejde "der gav ham Løn $i$ Gloden ved at udføre det". Personligt havde han altså usædvanlig mange lighedstræk med sin model.

\section{En Steno-epoke i dansk kunst}

Det ser ud til, at perioden fra 1886 til 1918, var en tid hvor flere danske kunstnere havde Niels Stensen på agendaen, en slags "Stenoepoke" i dansk kunst. Udover Laurits Jensen kan således nævnes Carl Hartmann, Frederik Vermehren, Oscar Matthiesen, Elias Ølsgaard, Emanuel Vigeland og Valdemar Neiiendam, alle kunstnere med Niels Stensen-arbejder fra omtalte tidsrum.

Den fornyede interesse for Niels Stensen kan sikkert relateres til den Internationale Geologkongres i 1881 og A.D. Jørgensens og W. Plenkers biografier (begge 1884). 200 års jubilæet i 1886 for Niels Stensens død var selvsagt heller ikke uden betydning. Vigtigt er det også, at den første danske oversættelse af Niels Stensens grundlæggende geologiske arbejde "De Solido" udkom i
1902, en oversættelse af J. Roses beskrivelse af Niels Stensens liv og død til dansk udkom i 1906 og "Opera Philosophica", Niels Stensens samlede videnskabelige publikationeri 1910.

\section{Hartmanns og Ølsgaards portrætbuster} Carl (Christian Ernst) Hartmann blev født 1837 i København og døde 1901 sammesteds. Han var billedhugger og arbejdede især med motiver fra antikken. Hans portrætbuste af Niels Stensen i Jesu Hjerte Kirke i København er ifølge J.B. Metzler modelleret til bronze efter anvisning af Wilhelm Plenkers, Niels Stensen biograf af tysk oprindelse. Denne buste blev fremstillet til 200 års dagen for Niels Stensens død, dvs. 25 november 1886 , og viser ham $i$ almindelig præstedragt, men med bispekors. Ifølge

A.L. Thomasen er det denne buste som er afstøbt og i dag kan ses i STENO-apotekets udstillingsvindue. Klædedragten og korset er imidlertid helt anderledes og ansigtet på sidstnævnte buste er mere præget af askese. Apotekets portrætbuste er signeret E. Ølsgaard og fremstillet $i$ bronze af billedhuggeren Elias (Rasmussen) Ølsgaard. Ifølge J.B. Metzler blev busten bestilt hos Ølsgaard som en gave fra lektor Tuxen til den Kgl. Landbohøjskoles mineralogiske samling $i$ år 1900 .

Den findes også som gipsafstøbning (dateret 1904) på henholdsvis Steno Diabetes Center (tidligere Niels Steensens Hospital) og på Niels Steensens Gymnasium. Fælles for Hartmanns og Ølsgaards buster er imidlertid at begge billedhuggeres forlæg sandsynligvis har været professor C.A. Lorentzens portrætmaleri af Niels Stensen fra 1800tallets begyndelse (maleriet er i dag på Panum Instituttet), eventuelt for Ølsgaards vedkommende maleren(Johan) Frederik
(Nicolai) Vermehrens minutiøse kopi af dette maleri fra 1888/89 (i dag på det Nationalhistoriske Museum på Frederiksborg Slot). Ølsgaards buste er den, som ligner mest på forlægget, især i klædedragt og kors.

Elias Ølsgaard var født i Hyum ved Jelling i 1873 og døde i Århus i 1964. Han var en uhyre produktiv kunstner, som især er kendt for sine monumenter, buster og relieffer af politikere og andre offentlige personer. I sin kunst lagde han vægt på, at det han fremstillede altid skulle ligne mest muligt. Hans mening var at, hvis arbejdet ikke lignede, var det ikke sandt. Dette forklarer, hvorfor hans buste af Niels Stensen ligner maleriet så godt.

Matthiesens og Vigelands freskoarbejder Maleren Professor Oscar (Adam Otto Wil- 


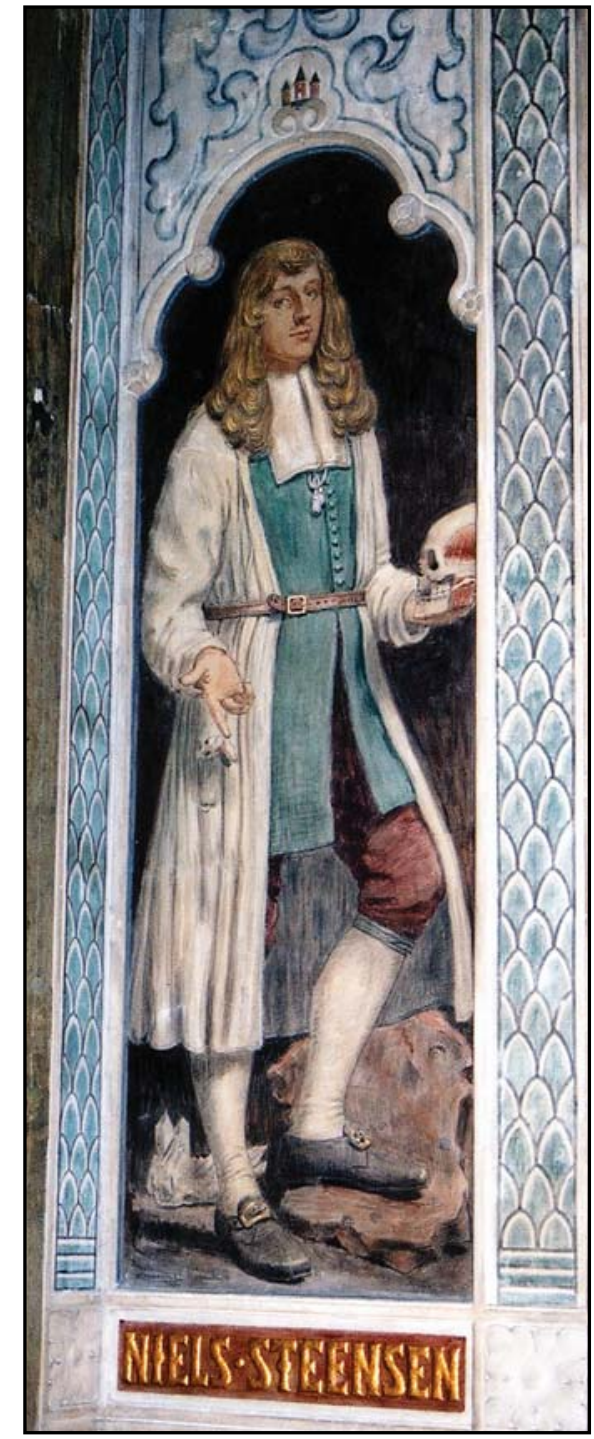

Emanuel Vigelands fresko på Københavns Rådhus. (Foto: Forfatteren)

liam) Matthiesen blev født i Slesvig $1861 \mathrm{og}$ døde i København 1957. Hans freskoarbejder som udsmykker Geologisk Museums vestibule, trappe og kuppelhal er til ære for Niels Stensen - "GEOLOGIAE

PARENTT'. Selve billedet af Niels Stensen, som viser denne i et toscansk landskab uden for Firenze, viser efter kunstnerens eget ud-

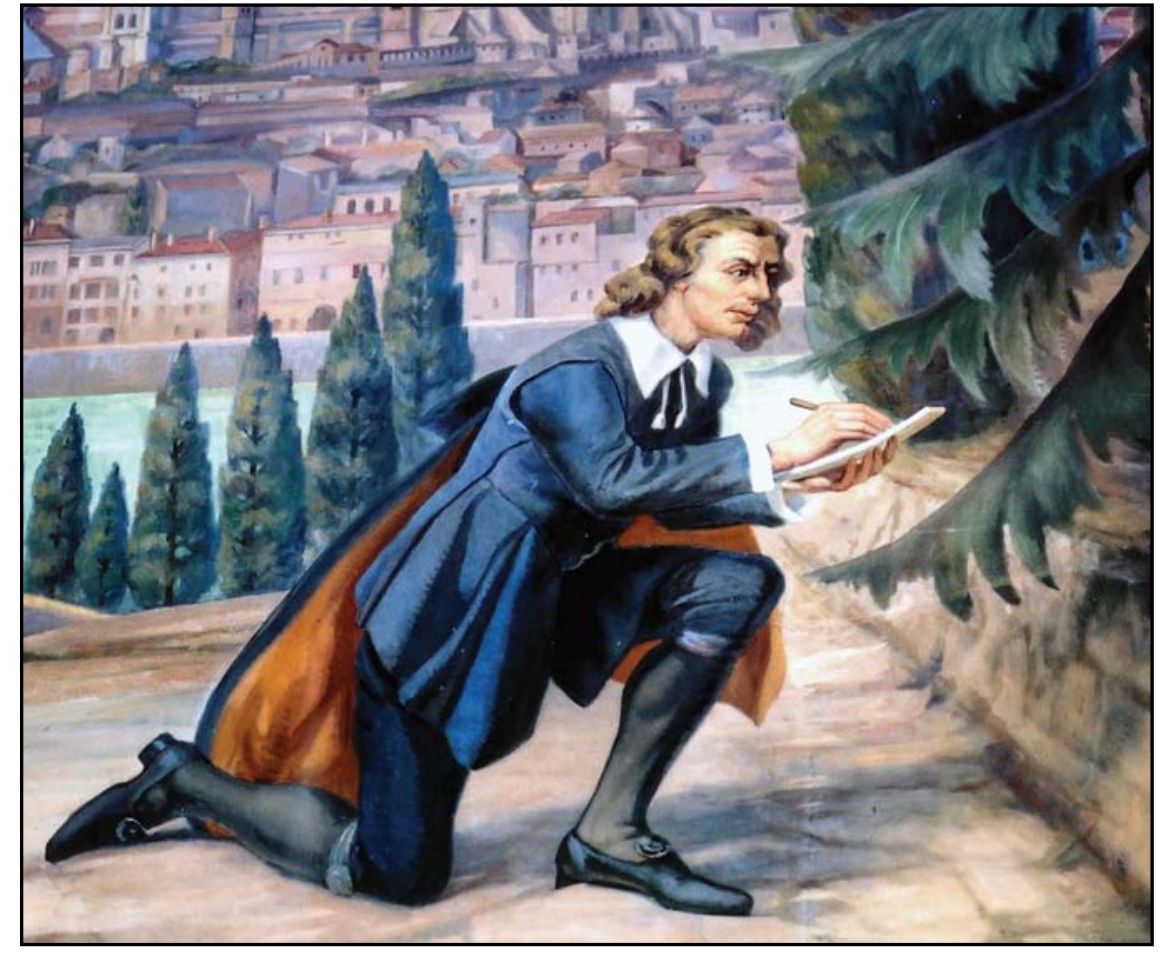

Oscar Matthiesens fresko på Geologisk Museum. (Foto: Forfatteren)

sagn Niels Stensen "tegnende en lagformation i det øjeblik, hvor hans forskerøje ser, at disse lag må voere dannet $i$ vand og flyttet herop ved vulkansk virksomhed'. Hele arbejdet blev oprindeligt indleveret som et konkurrenceprojekt til guldmedalje allerede i 1896, men blev ikke antaget. Først senere fulgte antagelse og mulighed for at realisere det. Det blev endeligt overtaget af Københavns Universitet i 1940. Undervejs havde man bl.a. bekostet flere års ophold for Matthiesen og hans familie i Toscana, for at han bedre kunne sætte sig ind i Niels Stensens verden. Ikke alle var glade for denne disponering af knappe midler (V. Poulsen pers. kom. 2004).

Et andet freskoarbejde, som også viser Niels Stensen relateret til geologi, er Emanuel (August) Vigelands værk, som kan ses på Københavns Rådhus. Denne usædvan- lige, pastelfarvede og stiliserede, nærmest art nouveau-agtige fremstilling, viser Niels Stensen dels som anatom, dels som geolog, bl.a. ses en bjergkrystal i baggrunden. Niels Stensen er fremstillet som en høj, kraftig person, men var i virkeligheden lille og spinkel af bygning. J.B. Metzler mener, at den overdrevne størrelse kan begrundes symbolsk, som et udtryk for stort åndeligt format. Freskoen er dateret 1905.

Emanuel Vigeland blev født 1875 i Mandal i Norge og døde 1948 i Oslo. Han var bror til billedhuggeren Gustav Vigeland, kendt fra Vigelandparken og museet i Oslo.

\section{Valdemar Neiiendams malerier}

Den sidste kunstner, som skal omtales her, er maleren Valdemar (Carl) Neiiendam, som blev født 1870 i København og døde 1956 sammesteds. Neiiendam var meget interes- 

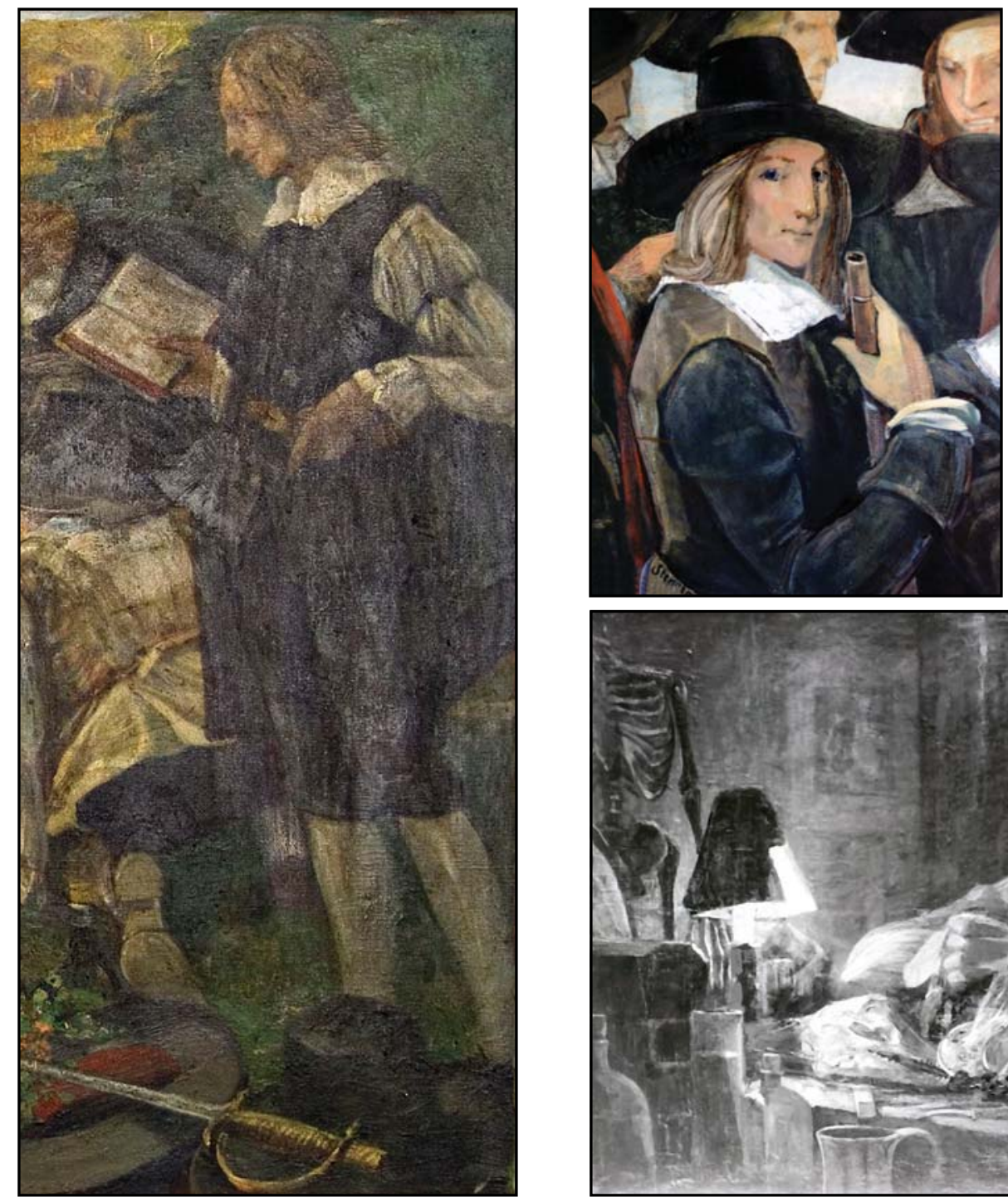

\section{Valdemar Neiiendam-malerier}

(A) Niels Stensen på botanisering. Udsnit af maleri som viser Ole Borch med studenter. Maleriet ejes af Haderslev Museum. (Foto: Haderslev Museum)

(B) Studenten Niels Stensen på Volden i 1659. Udsnit af maleri som findes på Medisinsk Museion. (Foto:Forfatteren)

(C) Niels Stensen studerer anatomi i Leiden (Foto: Det Kgl. Bibliotek).

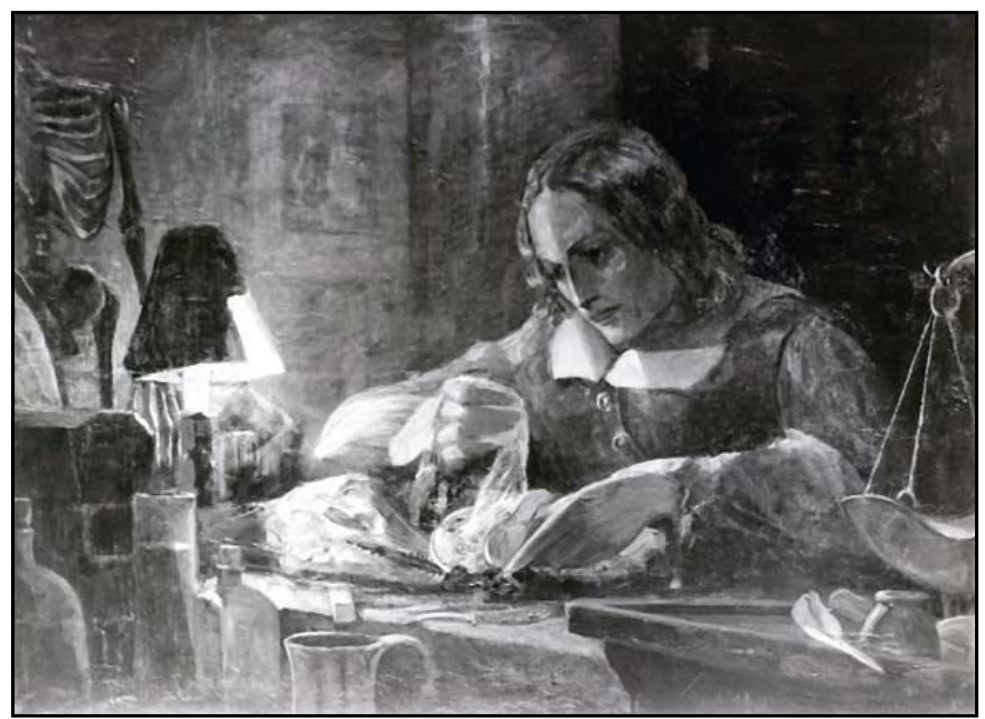

seret $\mathrm{i}$ historiemaleriet og malede ofte historiske personer fra videnskabens eller litteraturens verden i opdigtede hændelser. I en personlig indberetning hedder det: "Min Straben har varet at skildre historiske Skikkelser i Skabnepres, saavidt muligt med Anskuelighed i Lokalitet og Situation".

Neiiendam malede flere malerier af Niels Stensen. H.C. Christensen har registreret syv malerier i en fortegnelse fra 1944 over kunstnerens malerier.

1. "Ole Borch med Studenter på botanisk Udflugt i Ordrup Mose" dateret 1918 nu på Haderslev Museum. Personen yderst til højre, som ses fra siden, er sandsynligvis Niels Stensen. Dette ser man først, når man sammenligner personens udseende med de andre Neiiendam-maleriers fremstilling af Niels Stensen. Dette maleri er også omtalt med to andre titler, henholdsvis "Ole Borchs studenter på botanisk udflugt i Ordrup Mose" og "Ole Borch (f. 1626 - d. 1690) professor $i$ Chemi og Botanik ved Kjøbenhavns Universitet paa botanisk $U d$ flugt med Studenter i Ordrup Mose." Niels Stensen havde Ole Borch som lærer på latinskolen og blev immatrikuleret som student på Københavns Universitet 11656.
2. "Steno og andre Studenter paa Volden under Belejringen 1659" dateret 1918 og indkommet til Medicinsk Historisk Museum, nu Medicinsk Museion, i 1929. Dette billede omtales som et udkast til et maleri, der aldrig blev til noget. Billedet kan være inspireret af Kristian Zartmanns skitse af samme motiv fra 1888, eftersom Neiiendam var elev af denne kunstner. En anden titel er "Steno mellem andre Studenter paa Volden 1659".

Det er i øvrigt tvivlsomt, om Niels Stensen var på Volden under selve stormen på København, selvom det vides, at han var indrulleret $i$ et kompagni af studenter under svenskernes belejring af København. Ledige stunder under belejringen brugte han til selvstudier af datidens vigtigste naturvidenskabelige og filosofiske værker. Niels Stensens notater, det såkaldte "Chaos-manuskript" blev genfundet 11946 i Firenze og udgivet $i$ sin helhed af A. Ziggelaar i 1997.

\section{3. "Steno i Leyden, dissekerende et} Faarehoved", dateret 1918, ukendt opholdsted, dokumenteret i form af sort-hvidt fotografi. I 1660, kort efter sin ankomst til Amsterdam, fandt Niels Stensen Ductus Stenonianus (Stenos gang) ved at disse- kere et fårehoved. Dette var hans første anatomiske opdagelse.

4. "Steno besøger Spinoza i Rijnsburg", dateret 1918, ukendt opholdsted, dokumenteret i form af sort-hvidt fotografi. Niels Stensen kendte filosoffen Benedict (tidligere Baruch) Spinoza godt, og man troede tidligere, at han besøgte denne i landsbyen Rinjsburg under sin studietid i Leiden. Det var imidlertid Spinoza, som rejste ind til Leiden for at overvære Niels Stensens dissektioner. Niels Stensen studerede medicin ved Universitetet i Leiden fra 1660-1663. P. Totaro har for nylig skrevet om forholdet mellem de to.

5. "Steno i Italien foretager Jordbundsundersøgelser", dateret 1943, ukendt udseende og opholdsted, se også maleri nr. 6 .

6. "Steno under geologiske Undersøgelser i Italien", dateret 1943 (illustration næste side). Dette maleri, eller maleri nr. 5, blev fundet under arbejdet med denne artikel $i$ form af et farvefotografi $i$ et auktionskatalog. Maleriet har været udbudt til salg uden reference til Niels Stensen, men det fremgår klart, at han er selve motivet. Desværre har 
det ikke været muligt at opspore dette meget smukke arbejde, som viser Niels Stensen, der sidder og skriver feltnotater foran et geologisk profil. 300 år etter "De Solido" udkom, blev Niels Stensens geologiske arbejder publiceret på engelsk i 1969, redigert af den navnkundige Steno-forsker G. Scherz.

7. "Steno i Florens", dateret 1943, ukendt udseende og opholdsted.

Hvis nogen har kendskab til, hvor de sidste fem malerier er, så bedes de venligst tage kontakt med forfatteren.

Afslutningsvis vil jeg gerne takke Danmarks Kunstbibliotek, især Weilbachs Arkiv og Kunsthistorisk Billedarkiv for værdifuld hjælp. Geologisk Museum, Jesu Hjerte Kirke, STENO-apoteket, Panum Instituttet, Medisinsk Museion og Københavns Rådhus takkes for tilladelse til gengivelse af statuette, buster, freskoer og malerier/udsnit af malerier. Haderslev Museum hjalp med billedet af deres maleri af Ole Borch med studenter. Anne Gundersen, Tromsø Museum Universitetsmuseet, scannede og bearbejdede billederne.

\section{Litteratur}

Hartmann, S. (Red.) 1994-2000:

Weilbach: Dansk Kunstnerleksikon. Munksgaard, København.

Kermit, H. 2003: Niels Stensen. The Scientist who was beatified. Gracewing, Herefordshire. $179 \mathrm{pp}$.

Metzler, J. B. 1911: Nicolaus Steno i maler- og billedhuggerkunst. Varden 9, 163-178.

Scherz, G. 1988: Niels Stensen: Eine Biographie Band I-II. St. Benno-verlag, Leipzig.

Steno, N. 1902: Foreløbig meddelelse til en afhandling om faste legemer, der findes naturlig indlejrede $i$ andre faste legemer. Gyldendal, København. 106 pp.

("De Solido" oversat af A. Krogh og V. Maar).

Stensen, N. 1969: Steno Geological

Papers. Acta Historica Scientiarum

Naturalium et Medicinalium 20, Odense

University Press, Odense. 370 pp. (redigeret af G.Scherz).

Thomasen, A.-L. 1989: Der Wandel des Stensenbildes. I: Bierbaum, M. \& Faller, A. : Niels Stensen. Anatom, Geologe und Bischof. 1638-1686. Aschendorff,

Münster. 152-166.

Ziggelaar, A. 1997: Chaos: Niels Stensens Chaos-manuscript Copenhagen 1659. Complete edition with Introduction, Notes and Commentary. Acta Historica Scientiarum Naturalium et Medicinalium, 44. Munksgaard, København, 520 pp.

Fulstcendige referencer fås ved henvendelse til forfatteren på email:

elsebeth@tmu.uit.no

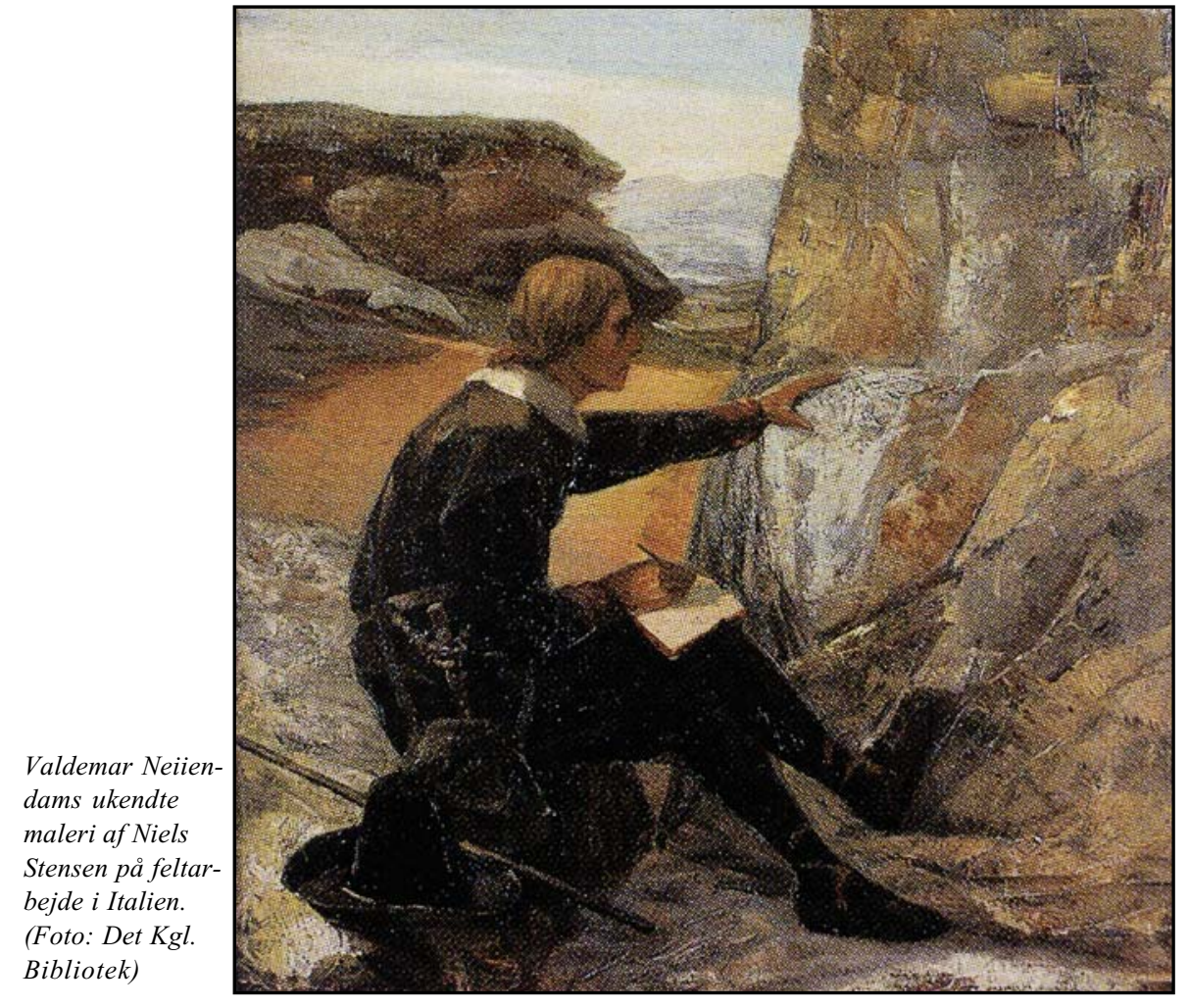

\section{Alverdens geologer mindes Steno}

Den første geologkongres

Ideen om at afholde internationale geologiske kongresser stammer fra professor Giovanni Capellini (1833-1922), som var ansat ved Universitetet i Bologna. Cappelini ønskede at skabe et stort geologisk museum i Bologna og rejste meget. Han indså derfor, at der var behov for et internationalt forum, for at man kunne blive enige om stratigrafi, palæontologi og kortlægning. Resultatet af hans virksomhed blev et nyt museum i Bologna og stiftelsen af den Internationale geologiske kongres (IGC) i 1876 i New York. Den første kongres fandt sted i Paris i 1878, og den anden 1881 i Bologna med Cappelini som præsident.

\section{Den første mindetavle}

Efter kongressen tog man blandt andet til Firenze, hvor man besøgte Niels Stensens daværende grav i krypten på basilikaen San Lorenzo. Her holdt orientalisten Valdemar Schmidt (1836-1925), som var den eneste danske deltager, et foredrag om Niels Stensen. Da den daværende mindetavle fra 1687, som nu er placeret over sarkofagen i Capella Stenoniana, ikke omtalte Niels Stensen som videnskabsmand, bestemte man sig for at samle midler ind til et minde over hans indsats som geolog og anatom. I 1883 blev en mindetavle sammen med et portrætrelief af Niels Stensen sat op i det tilstødende kloster. Portrættet var udført af den italienske billedhugger, professor Vincenzo Consani, sandsynligvis med forlæg $\mathrm{i}$ et relief $\mathrm{i}$ terracotta fra 1600 -tallet. På tavlen står (oversat fra latin):
Du ser, gaest, et billede af Niels Stensen. Over tusinde larde fra hele Verden har ved en penge-indsamling ladet det opscette til minde om den dag, den 4. oktober 1881, da geologerne efter en kongres, holdt i Bologna med Ridder Giovanni Capellini som prosident, drog hertil og under overvarelse af reprasentanter for Firenzes byråd og universitetet med orens laurborkrans taknemmeligt hoedrede støvet til den mand, sarligt fremragende geolog og anatom, hvis jordiske levninger hviler i krypten under denne kirke.

En plakat og den anden mindetavle Kongressen 1960 blev lagt til Norden med København som værtsby. Denne kongres havde som symbol en plakat, som viste Niels Stensen med tre illustrationer, en palæontologisk, en krystallografisk og en stratigrafisk, hentet fra hans publikationer. Plakaten var udført af Bruno Figalle, som har brugt Uffizimaleriet som forbillede.

Den seneste kongres fandt sted i Firenze sidste år. Her blev Niels Stensen fejret igen med en ny mindeplade ved siden af sarkofagen. Denne gang valgte man at fremhæve de geologiske fagfelter stratigrafi og krystallografi:

Niels Stensen naturforsker, biskop, saligkåret, mindes taknemmeligt for sin betydningsfulde fortjeneste, at han $i$ Firenze som den første opdagede stratigrafi og krystallografi, af geologer fra hele Verden, efter 123 ar igen kommet sammen $i$ Italien, for at afholde deres 32. kongres, august 2004 e. Kr. 